\title{
Empirical Study on the Financing Behavior Preference of the A-Share Listed Companies from Chinese Shanghai and Shenzhen Based on Earnings
}

\author{
Miao Yu, Zhen-Hong Xiao \\ School of Economics and Management, Harbin Engineering University, Harbin, China \\ E-mail: 1941352330@qq.com,xzh6030795@sina.com
}

\begin{abstract}
With the increasing perfection of the capital market, the financing behavior of the listed companies has become more and more mature. Every enterprise must finance, because financing as an important part of modern enterprise, can provide sources of funds to effectively guarantee enterprise and long-term business operations. In this paper, the A-share listed companies of 2011-2013 Chinese Shanghai and Shenzhen has been selected as the research objectives, and the degree of their preference on financing behavior was empirically tested based on the appropriate quotas of earnings. Conclusions: earnings manipulation is positively correlated with equity financing preference, earnings reliability, earnings cash security and earnings operation are negatively correlated with equity financing preference, respectively. Finally, the countermeasures are put forward to optimize the financing behavior of listed companies from Chinese Shanghai and Shenzhen A shares.
\end{abstract}

Keywords-Listed Companies; Financing Behavior; Financing Preference

\section{INTRODUCTION}

In contemporary society, listed companies have become main force in the development of enterprises by relying on a larger scale of production and strong market competitiveness. Development of listed companies has played an indispensable role model for these enterprises, which can measure economic level of a country, effectively improves the capital market, and rationally allocates resources. In order to surviving, a listed company must have financial support, which provides a income source for the normal operation of company, expands production scale, and enhances self value. So, the financial support possesses a certain role in promoting the development of listed companies.

Financing behavior is a kind of economic behavior of financing and fund-raising of listed companies to meet financial needs, and it is the core financial problems of listed companies. Basing on the maximizing personal interests of related subject, financing preference, namely a mean of effective sequence for different financing methods to affect the company business [1]. $\mathrm{n}$ a certain period of time, the enterprise financing is the accumulation of different financing behaviors, which forms a unique enterprise capital structure, and become a dynamic process. Capital structure and financing behavior complement each other. The difference on financing behavior of the enterprises determines the structure of corporate capital. At the same time, the structure of corporate capital has effect on the financing costs of enterprises. Further, the corporate finance behavior has effect on the economic benefits of enterprises. The relation between them based on the theory of capital structure gradually is concerned by the experts with the development of the theory of capital structure [2, 3].

At present, the financing behavior preference and earnings management of the listed companies in China have been studied, separately. The relation between financing and financing behavior preference is empirically researched through the selecting appropriate quotas. However, a few reports focus on the relationship between earnings management and financing behavior preference. In the current study, the financing behavior preference is empirically analyzed on the basis of earnings.

\section{THEORETICAL ANALYSIS}

\section{A. Basis for Selection of Earnings}

The capital structure plays a key role on a strong preference for equity financing of Chinese listed companies, and it is an important index to reflect the financing preference. By selecting the asset liability ratio as the explained variable, the relations of explanatory variables are studied, and equity financing preference of Chinese listed companies is concluded. The study on the financing behavior preference namely is the research on capital structure. At the same time, capital structure has relation with earnings quality; high quality earnings allow enterprises sustainable and stable operations. Forecast value of earnings is decided by earnings stability, growth and security. Using the data of the listed companies in China, appropriate variables such as earnings manipulation, earnings reliability, earnings cash security and earnings operation are chosen, and the financing preference behavior has been studied by the method of multiple regression analysis, the model is set up. The equity financing preference of Chinese listed companies is tested empirically and analysed [4].

\section{B. Variable Definition and Hypothesis}

Under the existing conditions, the effect of external macro environment on financing decision is deleted, the actual operating conditions of the company are considered, the variables, such as earnings security, earnings reliability and earnings operation are used as explanatory variables. The definition of variables and assumptions are shown in Table 1. 


\section{1) Earnings manipulation}

The difference in holding assets of companies brings different level earnings and has effects on the earnings manipulation. It is necessary to use accounting or non accounting means to change the current-account earnings for sustained and stable development of companies.

Research hypothesis H1: Earnings manipulation is positively correlated with asset liability ratio.

\section{2) Earnings reliability}

To achieve the optimal capital structure, an enterprise must ensure earnings at a good level. The larger operation scale of enterprise is, the higher operating profit is. So large enterprises often prefer to reduce the asset liability ratio. Therefore, earning reliability is negatively correlated with high or low level of asset liability ratio. The earnings reliability is measured using operating profit.

Research hypothesis H2: Earnings reliability is negatively correlated with asset liability ratio.

\section{3) Earnings cash security}

Earnings cash security guarantees cash income of the current net profit of the company, reflects the level of corporate earnings quality, and has influence on the company growth. The higher growth will have good promotion effect on the investment decision, and has extensive investment choice.

Research hypothesis H3: Earnings cash security is positively correlated with asset liability ratio.

\section{4) Earnings operation}

Earnings operation is namely the ability of business operation. In the current financing environment, the phenomenon of controlling rights of large shareholders gradually revealed, earnings operation is also affected. In order to avoid infringement of their interests, major shareholders of the company choose other means of financing, such as debt financing. Equity concentration is positively correlated with debt financing, In other words, the higher equity concentration is, and the higher level of debt is.

Research hypothesis H4: Earnings operation is positively correlated with asset liability ratio.

\section{EMPIRICAL TEST}

\section{A. Sample Selection and Data Sources}

Firstly, taking into account the availability of data, the listed companies of Chinese Shanghai and Shenzhen A-share in 2011-2013 are selected as samples. According to the need of research, the following screening: some companies including ST companies, IPO firms, listed companies of the financial and insurance industry, and the companies of incomplete data are removed. Besides, the data source is the GuoTai'an database and Wind database.

\section{B. Regression Model Selection}

According to the availability of data, the listed companies of Chinese Shanghai and Shenzhen A-share in 2011-2013 are selected as research samples, the impact factors of equity financing preference are analyzed empirically. Using statistical regression method by SPSS software, regression model is obtained as follow:

$$
Y=\alpha+\beta_{1} X_{1}+\beta_{2} X_{2}+\beta_{3} X_{3}+\beta_{4} X_{4}+\varepsilon
$$

In the regression model, $\alpha$ is a constant term, $\beta_{1}, \beta_{2}, \beta_{3}$ and $\beta_{4}$ are the coefficient of each variable, and $\varepsilon$ is the error term.

The significance of influence on the equity financing preference of listed companies is determined by coefficient $\beta$. If coefficient $\beta$ is not equal to zero, the difference is significant. Otherwise, the impact is not obvious if coefficient $\beta$ is zero [5].

TABLE I. VARIABLE DEFINITIONS AND HYPOTHESES

\begin{tabular}{|c|c|c|c|c|}
\hline Variable classes & Variable meaning & Variable symbol & Variable definition & $\begin{array}{l}\text { Correlation } \\
\text { prediction }\end{array}$ \\
\hline Explained variable & Asset liability ratio & $\mathrm{Y}$ & Total liabilities/Total assets*100\% & \\
\hline \multirow{4}{*}{ Explanatory variables } & Earnings manipulation & $\mathrm{X}_{1}$ & $\begin{array}{l}\text { (Total profit-Yield-Net non-operating } \\
\text { income)/Total profit*100\% }\end{array}$ & $\begin{array}{l}\text { Positive } \\
\text { correlation }\end{array}$ \\
\hline & Earnings reliability & $\mathrm{X}_{2}$ & Operating profit/Total profit $* 100 \%$ & $\begin{array}{l}\text { Negative } \\
\text { correlation }\end{array}$ \\
\hline & Earnings cash security & $\mathrm{X}_{3}$ & $\begin{array}{c}\text { Net cash flows from operating } \\
\text { activities/Main business income* } 100 \% \\
\end{array}$ & $\begin{array}{c}\text { Positive } \\
\text { correlation }\end{array}$ \\
\hline & Earnings operation & $\mathrm{X}_{4}$ & $\begin{array}{c}\text { Total profit/(Main business cost }+ \\
\text { Operating expenses+ Management } \\
\text { expenses + Financial expenses)* } 100 \%\end{array}$ & $\begin{array}{l}\text { Positive } \\
\text { correlation }\end{array}$ \\
\hline
\end{tabular}




\section{Empirical Analysis}

Using SPSS software statistical analysis, the results are shown in Table II, III, and IV.

The result of Table II is obtained by the regression equation analysis using method of least squares. According to Table II, the F-value (73.773) and sig. F $(<0.05)$ imply the fitting effect of model is better, and difference is significant.

TABLE II. MODEL R TEST

\begin{tabular}{|c|c|c|c|c|c|c|c|c|c|}
\hline \multirow{2}{*}{ Model } & \multirow{2}{*}{$\mathbf{R}$} & \multirow{2}{*}{$R$ square } & \multirow{2}{*}{$\begin{array}{l}\text { Adjusted } \\
\text { R square }\end{array}$} & \multirow{2}{*}{$\begin{array}{l}\text { Std. Error of } \\
\text { the estimate }\end{array}$} & \multicolumn{5}{|c|}{ Change statistics } \\
\hline & & & & & $\begin{array}{c}\text { R square } \\
\text { changes }\end{array}$ & F changes & $\mathbf{d f}_{1}$ & $\mathrm{df}_{2}$ & $\begin{array}{c}\text { Sig. F } \\
\text { change }\end{array}$ \\
\hline 1 & .227 & .051 & .051 & 21.066 & .051 & 73.773 & 4 & 5456 & .000 \\
\hline
\end{tabular}

TABLE III. PEARSON CORRELATION TEST ANALYSIS

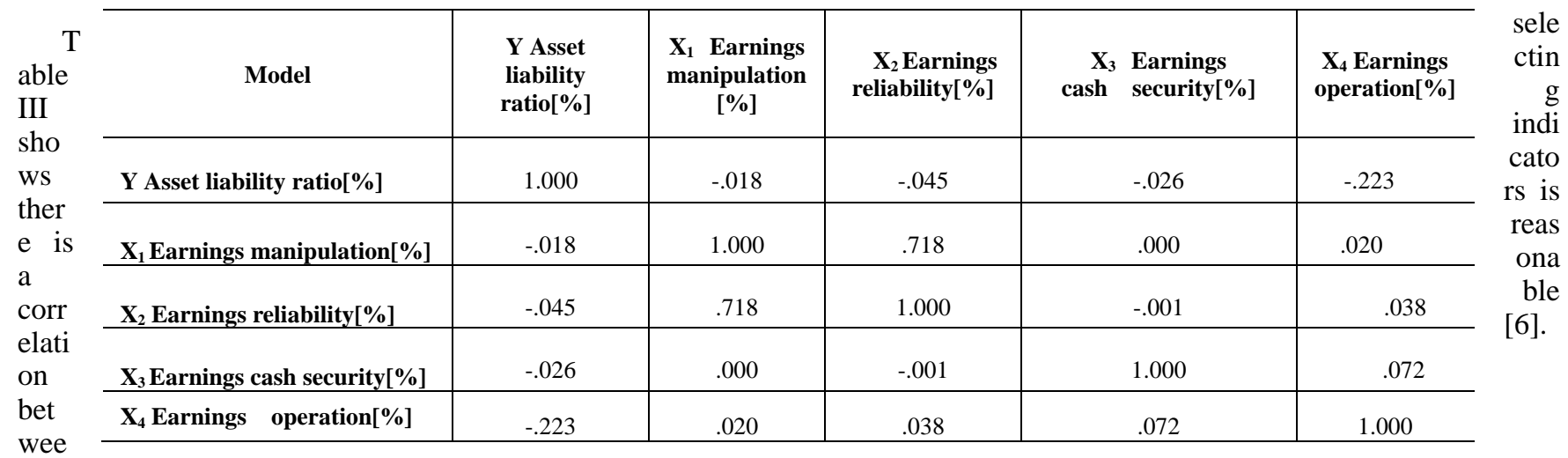

$\mathrm{n}$ explanatory variables and explained variable, and

TABLE IV. DESCRIPTIVE STATISTICS ANALYSIS

\begin{tabular}{c|c|c|c|c|c}
\hline \multirow{2}{*}{ Model } & \multicolumn{2}{|c|}{$\begin{array}{c}\text { Non standardized } \\
\text { coefficient }\end{array}$} & \multicolumn{2}{c|}{$\begin{array}{c}\text { Standard } \\
\text { coefficient }\end{array}$} & \multirow{2}{*}{ Sig. } \\
\cline { 2 - 5 } & $B$ & $\begin{array}{c}\text { Standard } \\
\text { error }\end{array}$ & $\beta$ & & \\
\hline Constant & 47.580 & .320 & & 148.775 & .000 \\
\hline $\mathbf{X}_{\mathbf{1}}$ Earnings manipulation[\%] & .001 & .001 & .026 & 1.352 & .176 \\
\hline $\mathbf{X}_{\mathbf{2}}$ Earnings reliability[\%] & -.005 & .002 & -.055 & -2.897 & .004 \\
\hline $\mathbf{X}_{\mathbf{3}}$ Earnings cash security[\%] & .000 & .001 & -.010 & -.763 & .446 \\
\hline $\mathbf{X}_{\mathbf{4}}$ Earnings operation[\%] & -.135 & .008 & -.220 & -16.650 & .000 \\
\hline
\end{tabular}

The following results are obtained from Table IV. :

The coefficient $(0.026>0)$ of earnings manipulation shows that explanatory variable $(\mathrm{X} 1)$ is positively correlated with asset-liability $\operatorname{ratio}(\mathrm{Y})$, and hypothesis $\mathrm{H} 1$ is established. This indicates that the stronger earnings manipulation is, the higher debt ratio is, which namely: the equity financing preference is more obvious. The information of investments obtained is not accurate due to a 
special stock issuance system in China, which lead investors to believe that a listed company has a good operating performance. Thus, the stronger earnings manipulation is the more obvious preference for equity financing of managers is. As a result, value of the bonds can not be played; the bonds are not conducive to issue in the market.

Earnings reliability coefficient $(-0.055<0)$ indicates that explanatory variable(X2) is negatively correlated with asset-liability $\operatorname{ratio}(\mathrm{Y})$, and hypothesis $\mathrm{H} 2$ is established. Thus earnings reliability can be measured by operating profit. The higher operating profit is, the lower the asset liability ratio is. Equity financing has become one of the most important choices of the financing way of listed companies; equity financing preference is more obvious.

Earnings cash security coefficient $(-0.010<0)$ shows that explanatory variable(X3) is negatively corr-elated with asset-liability $\operatorname{ratio}(\mathrm{Y})$, and the assump-tion $\mathrm{H} 3$ does not hold. It can be drawn that the higher th cash income of listed companies, the ower the asset liability ratio.

Earnings operation coefficient $(-0.220<0)$ shows that explanatory variable(X4) is negatively correlated with asset-liability ratio(Y), and the assumption $\mathrm{H} 4$ does not hold. It can clearly be seen that the stronger operating capability of the listed companies is, the lower asset-liability ratio is, which namely: the listed companies may be effectively promoted to continuously operate.

\section{SUGGESTIONS ON THE OPTIMIZATION OF CHINESE LISTED COMPANIES FINANCING BEHAVIOR}

Currently, in order to regulate the financing behavior of listed companies and make it reasonable and effective, an effective management system must be established. Thus, personnel of listed companies can perform their duties to avoid seeking only personal interests. Furthermore, we must establish a standard external supervision market, which monitor and manage the company managers to achieve the purpose of rational management company. On this basis, the equity constraint mechanism is gradually improved to weaken holding of company insiders, and realizes purpose of the equity incentives. At present, Chinese capital market is not complete and efficient; construction of market system is not perfect. In this case, the equity structure of a listed company must be adjusted, because the holding number of major shareholders is increased to change company management structure by forming equity structure of large shareholders. As a result, under market discipline mechanism the listed company will be innovative, and financing policy also is improved. In addition, the development of Chinese bond market and bond financing should be promoted actively, and different ways of financing are utilized so that capital market will be improved gradually $[7,8]$.

\section{ACKNOWLEDGMENT}

Postdoctoral scientific research in Heilongjiang province: research on the financing behavior and governance of listed companies based on managerial over confidence (LBH-Q12124).

\section{REFERENCES}

[1] T. C. Chiang, M. T. Yu, "Empirical finance of financial institutions and market behavior", International Review of Economics and Finance, vol. A43, pp. 1-2, May 2016.

[2] Z. Serrasqueiro, P. M. Nunes, "Financing behavior of Portuguese SMEs in hotel industry," International Journal of Hospitality Management, vol. A43, pp. 98-107, Oct 2014.

[3] Macan Bhaird C, "SME owners' financing preferences," Res-ourcing Small and Medium Sized Enterprises, vol.A5, pp. 77-103, 2014.

[4] C.P. Sun, "Research on the relationship between earnings quality and the rate of return on call warrants," Modern Business, vol. A2, pp. 46-47, 2013.

[5] F. Ni, "An empirical analysis on the financing preference of China's GEM listed companies," Shanghai International Studies University, China, 2011.

[6] X.L. Zhou, "An empirical study on the equity financing preference of listed companies in China", Hebei University of Technology, China, 2013

[7] M.Yang, "Research on the financing preference of listed companies," Communication of Finance and Accounting, vol.A20, pp. 17-20, 2015.

[8] L.Kang, "Analysis on capital structure and financing preference of listed companies," Communication of Finance and Accounting, vol. A11, pp. 24-25, 2012. 